UDC 621.51

\title{
METHOD OF UNCERTAIN COEFFICIENTS IN PROBLEMS OF OPTIMAL STABILIZATION OF TECHNOLOGICAL PROCESSES
}

Stenin A. A. - Dr. Sc., Professor of the Department of technical Cybernetics, Igor Sikorsky Kyiv Polytechnic Institute, Kiev, Ukraine.

Drozdovich I. G. - Senior researcher, Institute of telecommunications and global information space of NAS of Ukraine, Kiev, Ukraine.

Soldatova M. A. - Senior lecturer of the Department of automated information processing and management systems, Igor Sikorsky Kyiv Polytechnic Institute, Kiev, Ukraine.

ABSTRACT
Context. The equivalent transformation method is examined in the given article. Its essence lies in changing of a certain class of non-stationary systems with the stationary ones, for which optimization methods are well processed. Urgency of the method is determined by the fact that in most optimal control methods, developed for continuous systems, tasks are considered in the temporary space using the states space and the matrix theory. All real control objects are known to be non-linear and non-stationary in one way or another. Analysis and synthesis of control systems for such objects is a complex mathematical issue, and its solution is received for some separate occasions for now.

As a result of using the suggested method, when the variable coefficients matrix is known, the task of the non-stationary system optimal control is reduced to the task of the equivalent stationary system optimal control for which solution methods are well-known and well processed.

Objective. Reducing energy intensity and improving the quality of products of various technological processes is an urgent task of the national economy of Ukraine.

Methods. To achieve this goal, we propose a method of modal synthesis of optimal stabilization laws using the method of uncertain coefficients, developed by the authors

Results. Algorithm of synthesis of the optimal controller in the absence and presence of delay in the control loop is developed. The method of selection and correction of the desired spectrum of roots is proposed. To eliminate self-oscillations in the presence of a delay in the control circuit, the R. Bass method is used.

Conclusions. The modal synthesis of optimal laws of stabilization of technological processes is proposed on the basis of the original method of uncertain coefficients. The complexity of the choice of the desired eigenvalues is overcome by the proposed procedure of construction and correction of the spectrum of roots in a closed system of optimal control. To eliminate the occurrence of stable self-oscillations (in the presence of a delay) in the stabilization process near a given trajectory, the Bass's method is proposed to be used. The simulation results confirm the correctness and effectiveness of the results.

KEYWORDS: technological process, linear-quadratic optimization task, AKOR method, modal synthesis, method of uncertain coefficients, choice and correction of roots spectrum, R. Bass's method.

\author{
ABBREVIATIONS \\ ACOR - analytic construction of the optimal \\ regulators; \\ ACS - automatic control system.
}

$I(x, u)$ is a functional;

\section{NOMENCLATURE}

$T$ is a the symbol of transposition;

$t$ is a current time;

$\bar{u}$ is a vector of control actions;

$p_{i}$ are the feedback coefficients;

$\lambda i$ is a roots of the characteristic equation;

$i, j$ is a indexes;

$a_{i j}$ are the coefficients of the matrix $A$;

$b_{i}$ are the coefficients of the matrix $B$;

$c_{i j}, f_{i}, d_{i}$ is a auxiliary variable;

col is a column vector;

$k$ is a gain ratio;

$\widetilde{x}$ is a extended state vector;

$D$ is a determinant;

$D_{n}$ is a determinant of dimension $n \times n$;

$D_{n+1}$ is a matrix with $(n+1) \times(n+1)$ coefficients and $p \tilde{l}$ are column vectors with dimension $(n+1)$; $\varepsilon$ is a real part of the complex root;

$\xi$ is a degree of vibration damping;

$\varphi$ is a phase shift;

$\omega$ is a circular frequency of oscillation;

$\mu$ is a some ratio;

$\bar{x}(t)$ is a state vector;

$u(t)$ is a scalar control;

$\theta$ is a delay in the control loop;

$\omega$ is a circular frequency;

$f_{i}$ is a coefficient of the $i$-th open characteristic determinant.

$A^{*}$ is a matrix of constant coefficients of dimensions $(n+1) \times(n+1)$;

$B$ is a the column vector of dimension $(n \times 1)$;

$Q=\left\{q_{i j}\right\}$ is a diagonal matrix $(n \times n)$;

$H(\lambda)$ is a characteristic polynomial;

$q 11=q 22=q 33=1$;

$\operatorname{det}\left(A+B_{p}^{-T}-I \lambda\right)$ is a the characteristic determinant of a closed optimal system.

\section{INTRODUCTION}

Systems synthesis task is one of the key tasks of both automatic control theory and practice. Its solution results 
in definition of the structure of the automatic control system (ACS) and its parameters from the condition of the system sustainability and quality of transient processes (achieving the required performance, the inadmissibility of the considerable overshoot) improving control accuracy in steady-state conditions etc [1].

Linear controllers are an effective way to ensure dynamic performance of not only linear control objects of arbitrarily high order, but also of objects that contain nonlinear and discrete units, which have a significant, but not a determining influence on dynamic processes.

One of the important classes of dynamic objects are various technological processes. Stabilization of technological processes is the basis for the development of optimal control systems. As the result of successful stabilization and remote manual control, it is possible to facilitate the withdrawal of equipment and machinery to open areas, which leads to a significant reduction in specific capital costs when creating new production capacities. The task of the regulators stabilizing the technological process is to counter the perturbation by the introduction of restorative effects. The problem of automation is especially acute for enterprises of chemical and petrochemical industry [2].

The majority of industrial controlled objects have delays. The presence of the delay is due to the final velocity of information flows propagation in the technological objects. The delay may also occur due to time spent on signal transmission or, as in happens more often, in can be caused by the phenomenon of simplifying assumptions, by virtue of which it is considered that action of intermediate and reinforcing links in the controlled object is reduced to a signal transmission with delay. In these cases it is called transport delay systems [3].

Inertia of the operator himself has a significant impact on the management quality in addition to the delay in the signal transmission. Therefore, it's imperative to have optimal (reference) dynamic implementation (control laws) in preparation of the operator taking into account the inertia and delay in the control loop.

In this article authors propose a procedure for the synthesis of the optimal modal law stabilization of linear stationary systems with delay based on the method of undetermined coefficients, which is proposed by the authors below.

\section{PROBLEM STATEMENT}

Let the dynamics of the process have the form:

$$
\dot{\bar{x}}(t)=A \bar{x}(t)+B u(t-\theta)
$$

Boundary conditions:

The most common for the stabilization of technological processes is a quadratic criterion of shape quality:

$$
I(x, u)=\int_{0}^{\infty}\left[\bar{x}(t)^{T} Q \bar{x}(t)+u^{2}(t)\right] d t .
$$

The choice of the quality criterion (2) is due to the fact that it reflects the accuracy of tracking the normative indicators of technological processes and energy consumption for the stabilization process.

The General statement of the problem of stabilization of technological processes is as follows:

- it is necessary to find a control that translates the system (1) from an arbitrary initial state to a zero finite state and minimizes the quality criterion (2).

\section{REVIEW OF THE LITERATURE}

There are two main deterministic approaches to create the control system for the object's state vector - analytical design of optimal controllers and modal control.

Professor A. M. Letov [4] published his work in 1960, in which the analytical solution of the problem of linear stationary object's optimal stabilization with a quadratic quality functional was obtained, it was later called "analytic construction of the optimal regulators" (ACOR).

Problem of linear non-stationary objects optimization is also solved in Kalman's work [5] published in 1960.

ACOR has the ultimate goal of obtaining control law purely analytically, based on the requirements for management quality.

Synthesis of the desired optimal closed loop control system using ACOR depends on the designer choice of suitable coefficient values of quality criterion is not quite convenient because of absence of obvious relationship between selected coefficients and transients in a closedloop system.

In addition, the application of the ACOR method leads to the necessity of solving nonlinear matrix Riccati equation, which is a non-trivial task and requires the use of special numerical procedures [6].

The essence of the modal synthesis of optimal control is to determine the numerical values of the delayless feedback transmission coefficients in all the variables of the technological processes state in order to ensure a predetermined distribution of the characteristic equation roots (eigenvalues) in the closed-loop control system [7].

For optimal stabilization of the technological processes proposed modal synthesis using the method of uncertain coefficients. Let us first consider the case when there is no delay in the control loop.

\section{MATERIALS AND METHODS}

It is known [6] that for systems (1)in the case of a quadratic quality criterion (2), extreme control is a linear function of state variables:

$$
\bar{u}=p^{-T} \bar{x}
$$

Moreover, if the vector of feedback coefficients is chosen in such a way that the poles of the closed system (1) are located at preassigned arbitrary points, then the required dynamic properties will be provided in the closed system [4]. Thus, this problem is reduced to the choice of the optimal location of the poles and determination of the feedback coefficients.

We prove the following statement. 
Statement. We show that the unknown coefficients of the characteristic determinant of a closed optimal system [7]:

$$
\begin{aligned}
& \operatorname{det}(\lambda)=\left|A+B p^{-T}-I \lambda\right|= \\
& =\left|\begin{array}{l}
a_{11}+b_{1} p_{1}-\lambda \cdots a_{1 j} p_{j} \cdots a_{1 n}+b_{1} p_{n} \\
a_{j 1}+b_{j} p_{1} \cdots a_{j j}+b_{j} p_{j}-\lambda \cdots a_{j n}+b_{j} p_{n} \\
a_{n 1}+b_{n} p_{1} \cdots a_{n j}+b_{n} p_{j} \cdots a_{n n}+b_{n} p_{n}-\lambda
\end{array}\right|
\end{aligned}
$$

linearly enter into the expression for the coefficients of the characteristic polynomial of a closed system.

Proof. Indeed, let's suppose that. Then, subtracting the $k$-th line from the $\mathrm{j}$ th line, multiplied by we get a determinant equal to the original, in which the feedback coefficients enter the $\mathrm{k}$ th line. Expanding it along this line and grouping the terms with the corresponding powers, we finally arrive at the following expression of the characteristic polynomial of the closed system (4a) or (4b):

$$
\begin{array}{r}
H(\lambda)=\lambda^{n}+\left(\sum_{i=1}^{n} c_{n-1, i} p_{i}+d_{n-1}\right) \lambda^{n-1}+\left(\sum_{i=1}^{n} c_{0, i} p_{i}+d_{0}\right) \\
\left.H(\lambda)=\lambda^{n}+\left(\begin{array}{l}
-T \\
c^{n}-1
\end{array}\right)+d_{n-1}\right) \lambda^{n-1}+\ldots+\left(-T-\bar{p}+d_{0}\right) .
\end{array}
$$

We define the unknown parameters $c_{j i}$ and $d_{i}(j=\overline{0, n-1} ; i=\overline{1, n})$, in $n+1 \quad n+1$ step using the undetermined coefficients method. To do this, we put $p_{i}=0(i=\overline{1, n})$ in the characteristic determinant at the first step and reveal it by one of the known numerical methods and find that the coefficients found for different powers of $\lambda$ determine the unknown coefficients $d_{j}(i=\overline{0, n-1})$ in the expressions for the characteristic polynomial of the closed system for the corresponding powers of $\lambda$. In the next $n$ steps, setting sequentially one of the coefficients $p_{i}(i=\overline{1, n})$ equal to one while others remain zero and revealing the characteristic determinant, we obtain expressions for the unknown parameter $c_{j i}$, $\lambda^{j}(j=\overline{0, n-1}) \quad$ or $\quad$ the corresponding power $\lambda^{j}(j=\overline{0, n-1})$ in the characteristic polynomial of the closed system.

$$
c_{j i}=f_{i}-d_{i}
$$

On the other hand, the characteristic polynomial of a closed system with the desired roots $\lambda_{1}, \lambda_{2}, \ldots, \lambda_{n}$ has the form [7]

$$
F(\lambda) \prod_{i=1}^{n}\left(\lambda-\lambda_{i}\right)=\sum_{j=0}^{n-1} 1_{j} \lambda^{j}+\lambda^{n}
$$

As a result, to determine the feedback coefficients pi in expression (2), we equate the expressions for the coefficients for the same powers in (4) and (6) and obtain a system of linear algebraic equations:

$$
\operatorname{col}\left(\stackrel{-T}{C},-\frac{-T}{C}, \ldots,-, \bar{C}\right) \bar{p}=\overline{1}-\bar{d},
$$

where

$$
\overline{1}=\left(1_{n-1}, 1_{n-1}, \ldots, 1_{0}\right), \bar{d}=\left(d_{n-1}, d_{n-2}, \ldots, d_{0}\right) y .
$$

Now consider the procedure for modal synthesis based on the undefined coefficients method proposed for linear dynamical systems with transport delay $[5,6]$.

Let the dynamics model (1) of the technological process is described as

$$
\dot{\bar{x}}=A \bar{x}+B y,
$$

where $\bar{x}=\left(x_{1}, x_{2}, \ldots, x_{n}\right)^{T}$ is fully measured vector of system states deviation from a predetermined trajectory of movement; A,B is a coefficient matrix with dimension $n \times n, n \times 1 ; y$ is a scalar, characterized by deviation of controls, taking into account the reaction of the operator, the dynamic model has the form

$$
\dot{y}=\lambda_{y} y+d_{u} u(t-\theta),
$$

where $\lambda_{y}, d_{u}, \theta$ are constants determined by psychophysical features of operators (and besides $\lambda_{y}=-\frac{1}{T} ; d_{u}=\frac{k}{T} u(t)$ is a scalar control action, which will be sought in the form (2). The objective is to determine the coefficients $\bar{p}=\left(p_{1}, p_{2}, \ldots p_{n}\right)^{T}$, providing some predetermined dynamic characteristics of the stabilization process and achieving sustainable programmed movement of the system (8).

As the operator delay $\theta$ is sufficiently small value, we'll write the equation (9) as a

$$
\dot{y}(t)=\lambda_{y} y(t)+d_{u} u(t)-d_{u} \theta \dot{u}(t) .
$$

In that case if in some way estimate or measure the condition of the operator $y(t)$, the system (8), (10) is fully observed and the problem is solved as follows.

We take into consideration the advanced phase vector. Then the closing equation has the form

$$
\begin{gathered}
\widetilde{x}=\left(x_{1}, x_{2}, \ldots, x_{n}, x_{n+1}=y\right)^{T} . \\
u=p^{T} \widetilde{x},
\end{gathered}
$$

and the characteristic polynomial of the closed-loop system (8), (10) takes the form: 


$$
\operatorname{det}\left(A^{*}-I \lambda\right)=\left|\begin{array}{c}
A-I \lambda \\
\frac{d_{u}\left(\bar{p}^{T}-\theta \bar{p}^{T} A\right)}{1+d_{u} \theta} p_{n+1}
\end{array}\right| \frac{B}{\frac{\lambda_{y}+d_{u} p_{n+1}-\theta \bar{p}^{T} B}{1+d_{n} \theta} p_{n+1}} \mid=0,
$$

where $A^{*}$ is a matrix

$$
\begin{gathered}
(n+1) \times(n+1), \bar{p}=\left(p_{1}, p_{2}, \ldots p_{n}\right)^{T}, \\
\Delta_{11}=\Delta_{12}=\Delta_{21}=\Delta_{22} .
\end{gathered}
$$

The multiplication of all the elements of a row or column by the factor $\mu$ is equivalent to multiplying the determinant on $\mu$ [7]. Hence, the determinant (12) can be written and therefore assuming that the, we'll put

$$
\left|\frac{A-I \lambda}{\bar{p}^{T}-\overline{\theta p}^{T} A}\right| \frac{B}{\lambda_{y}+d_{u} p_{n+1}-d_{u} \overline{\theta p}^{T} B-\lambda\left(1+d_{u} \theta p_{n+1}\right)} \mid=0 .
$$

It is easy to show that the determinant (13) is a polynomial of degree $(n+1)$ on $\lambda$, and its coefficients are linearly dependent on , i.e.

$$
\operatorname{det}\left(A^{*}-\lambda \lambda\right)=H(\lambda, \bar{p})=\lambda^{n+1}+\left(\bar{d}_{n}^{T} \bar{p}+d_{n}^{0}\right) \lambda^{n}+\ldots+\left(\bar{d}_{n}^{T} \bar{p}+d_{n}^{0}\right)=0 .
$$

Indeed, when uncovering the determinant (13) in the last line, in which each element is a linear combination of the coefficients $p$, we're getting the expression (14).

Determination of unknown coefficients $d_{i}, d_{i}^{0}(i=\overline{0, n})$ is made similarly to the procedure cited in this paper above. When equating between the coefficients of the polynomial powers (14) and the polynomial with spectrum $\left\{\lambda_{i}\right\}(i=\overline{1, n+1})$ selected to provide specified quality parameters of transient processes

$$
L(\lambda)=\prod_{i+1}^{k+1}\left(\lambda-\lambda_{i}\right)=\sum_{k=0}^{n+1} 1_{k} \lambda^{k}
$$

where $l_{n+1}=1$, we get the joint system of linear algebraic equations

$$
D_{n+1} p=\tilde{l}
$$

The solution of system (16) provides the defined spectrum $\left\{\lambda_{i}\right\}(i=\overline{1, n+1})$ to a closed-loop system. Frequently it is not possible to evaluate or measure the state of the operator $y(t)$ in real conditions. Then it is necessary to put $p_{n}+1 \equiv 0$ in the closing equation (11). As a result, the characteristic determinant of a closed-loop system has the form.

$$
\operatorname{det}\left(A^{*}-I \lambda\right)=\left|\frac{A-I \lambda}{d_{u}\left(\bar{p}^{T}-\theta \bar{p}-T\right)}\right| \frac{B}{\lambda_{y}-d_{u} \overline{\theta p}^{-T} B-\lambda} \mid \text {. }
$$

Desired characteristic polynomial is determined, as in the previous case, by the expression (15). When equating the coefficients of the polynomials (17) and (15) with the same powers $\lambda$ we obtain incompatible systems of linear algebraic equations in contrast to (16)

$$
D_{n} \bar{p}=\tilde{l} \text {. }
$$

It is possible to use the least squares method [8] for solving such a system, according to which the vector of unknown coefficients $\bar{p}$ is approximately defined as

$$
\bar{p}=\left(D_{n}^{T} D_{n}\right)^{-1} D_{n} \tilde{l}
$$

The optimal stabilization law (11) of the system (1), synthesized, proposed by the method of indefinite coefficients, provides the given dynamic properties of the process of stabilization of the system in the event of deviations from the given (software) trajectory of motion. However, this law does not eliminate the occurrence due to the presence of a lag of stable self-oscillations at the end point of the stabilization process near the given trajectory of motion. To compensate for the delay, a modified Bass's method [8] proposed, the essence of which is as follows. The delay compensation method [8] to eliminate this effect, according to which it is necessary to find a surface spaced in delay time from the zero error point lying on the trajectory of the motion program (1) by integrating system (1) in reverse time. In fact, this surface is a tube inside which the programmed trajectory is located.

To ensure the specified dynamic parameters of transient processes in the stabilization of the technological processes below the proposed methodology for the selection and correction of the spectrum of the roots.

Usually in stabilization mode technological processes management quality is defined by transition process time tn.n. and a range of this process simplification

$$
\xi=\frac{x_{j}\left(t_{n . n}\right)}{x_{j}\left(t_{0}\right)}<1, \quad j=\overline{1, n} .
$$

If $\lambda_{0}=\varepsilon_{0}+i \omega_{0}$ is a dominant root then solution of system (1) can be approximately written in the form

$$
x_{j}=x_{j}\left(t_{0}\right) e^{\varepsilon_{0} i} \cos \left(\omega_{0} t+j_{i}\right), \quad j=\overline{1, n} .
$$

From equation (21) based on expression (20) we obtain

$$
\frac{x_{j}\left(t_{n . n}\right)}{x_{j}\left(t_{0}\right)} \leq e^{\varepsilon_{0} t_{n . n}} \leq \xi,
$$

where 


$$
\varepsilon_{0} \leq \frac{\ln \xi}{t_{n . n}}<0
$$

We choose such value of the imaginary part that is equal $1 /$ tn.n. Variable $x j(t)$ will make one oscillation around the equilibrium position at the same time during the transition process and will strive for it from the opposite side relative to the initial disturbance, which is highly desirable for physical reasons.

In order to avoid overshooting the remaining roots of the characteristic polynomial should be placed as close as possible to the dominant with implementation of such conditions

$$
\begin{aligned}
& \omega_{0}<\omega_{1}<\omega_{2}<\ldots, \\
& \left|\varepsilon_{0}\right|<\left|\varepsilon_{1}\right|<\mid \varepsilon_{2}<\ldots,
\end{aligned},
$$

so that components with the large fluctuations will dump more rapidly

$$
\left|\lambda_{k}\right|-\left|\lambda_{k-1}\right|>0,1\left(\left|\lambda_{k}\right|\right)
$$

and that the roots are not merged into multiples. It is desirable to have roots on the complex plane as much as possible to the left in order to reduce transition time. However, constraints on state variables impose certain restrictions on the roots modules too.

Given the notation (21) we write

$$
\dot{x}_{j}=\sqrt{\omega^{2}+\varepsilon^{2}} x\left(t_{0}\right) e^{\varepsilon t} \cos \left(\omega t+\varphi_{j}\right) .
$$

Each $j$-th equation of system (22) generates two upper limits of the roots modules in the characteristic polynomial, due to by the same restriction on the left and right sides of the $j$-th equation of system (22).

Taking into account the expression (25) we define that for the left side of the $j$-th equation of system (7)

$$
\max _{t} \max _{\lambda} x_{j}=\max \sqrt{\omega^{2}+\varepsilon^{2}} x_{j}\left(t_{0}\right)
$$

And for the right side

$$
\max _{t} \max _{\lambda} \sum_{i=1}^{n} a_{j i} x_{j} \leq \sum_{i=1}^{n}\left|a_{j i} x_{i}\left(t_{0}\right)\right|
$$

Comparing the expressions (26) and (27), in the absence of an explicit dependence of inequality (27) from the roots module the following inequality can be written as:

$$
\max _{\lambda} \sqrt{\omega^{2}+\varepsilon^{2}} \leq \frac{\sum_{i=1}^{n}\left|a_{j l} x_{i}\left(t_{0}\right)\right|}{x_{j}\left(t_{0}\right)} .
$$

(C) Stenin A. A., Drozdovich I. G., Soldatova M. A., 2020 DOI 10.15588/1607-3274-2020-1-21
The most severe restriction of (28) will give us the left edge of the characteristic polynomial root distribution. Thus, the increasing $\varepsilon$ in order to accelerate the decay process results in minimization $\omega$ considering expressions (23) and (24). Roots location corrected after the transient modeling, based on the superimposed state variables limits by changing the characteristic polynomial coefficients.

Let's suppose that the $\mathrm{j}$-th state variable is constrained by $\max \left|x_{j}\right| \leq x_{j}^{\text {pres }}$. In this case, we homothetically shift all roots relative to the origin (according to Vieta's theorem) with the homothetic coefficient by multiplying coefficients of the characteristic polynomial of degree 1 by the value $\left[\frac{x_{j}^{\text {pres }}}{x_{j}}\right]$ [9].

Also, the value of $\max \left|x_{j}\right|$ will change according to the expression (21).

\section{EXPERIMENTS}

We will carry out modeling for two types of technological processes, dynamic models of which are most common in practice. The aim of the simulation is a comparative analysis of the transients obtained by the standard ACOR method and modal synthesis based on the method of uncertain coefficients.

Technological process 1 . Let the dynamics of the technological process described by a system of equations of the form:

$$
\frac{d x_{1}}{d t}=x_{2} ; \quad \frac{d x_{2}}{d t}=a_{22} x_{2}+b_{2} u .: \quad a_{22}=1 ; \quad b_{2}=1 .
$$

Thus, the control object is a serial connection of the integrating and aperiodic links. It is necessary to define a control law that provides a minimum of the functional (2).

Boundary conditions:

$$
x_{1}(0)=x_{10}, \quad x_{2}(0)=x_{20} ; \quad x_{1}(\infty)=x_{2}(\infty)=0 .
$$

We consider two cases: a) $x_{10}=1 ; x_{20}=0$; b) $x_{10}=5$; $x_{20}=0$;

On the Fig. 1 graphics of transients of stabilizing for cases a), b) obtained by ACOR and modal synthesis, , is shown.

Technological process 2. Now let's suppose that the dynamics of the technological process is described by a system of equations of the form:

$$
\dot{\bar{x}}(t)=A \bar{x}(t)+B u(t), \bar{x}(t),
$$

where $\bar{x}(t)=(x 1(t), x 2(t), x 3(t)) \mathrm{T}$-state vector; $u(t)-\mathrm{a}$ scalar control.

We assume that the delay in the control loop is missing. 
Let's also assume that $A=\left(\begin{array}{lll}-1 & 1 & 0 \\ 0 & 0 & 1 \\ -1 & 0 & 0\end{array}\right)$ and $B=\left(\begin{array}{l}0 \\ 0 \\ 1\end{array}\right)$.

For the stabilization of technological process a quadratic criterion of shape quality (2) is used,

We consider two cases: a) $x_{10}=1 ; x_{20}=0 ; x_{30}=0$;

b) $x_{10}=5 ; x_{20}=0 ; x_{30}=0$,

\section{RESULTS}

On the Fig. 1 shows graphics of transients of stabilizing for cases $\mathrm{a}$ and $\mathrm{b}$ obtained by ACOR and modal synthesis for the technological process 1 .

On the Fig. 2 graphics of transients of stabilizing for cases $\mathrm{a}$ and $\mathrm{b}$ obtained by ACOR and modal synthesis for the technological process 2 .
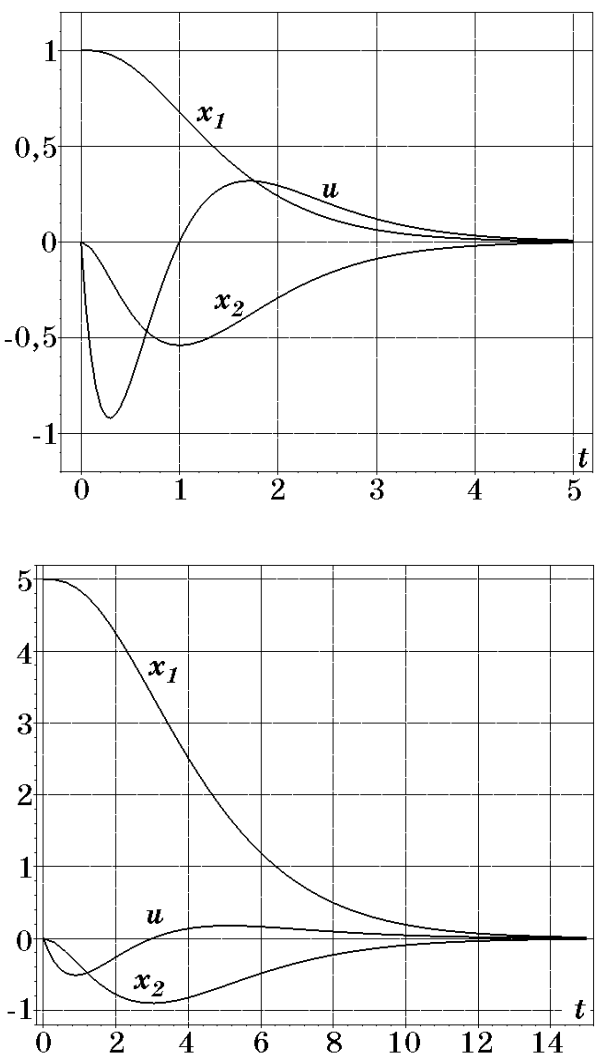

\section{DISCUSSION}

From these graphics (Fig. 1 and Fig. 2) we can see that from the point of view of modal synthesis, providing the given dynamic parameters of the transient stabilization processes is more effective. On the Fig. 1 it concerns the energy saving component. On the Fig. 3 it concerns to the accuracy of tracking the required stabilization parameter values. With the help of the proposed modal synthesis based on the method of uncertain coefficients, it is possible to ensure the performance of such dynamic indicators of the quality of transients as: stabilization time, overshoot, simplification, degree of oscillation, etc. This is the main advantage of this method over the ACOR method, since the latter does not have a direct relationship between the coefficients of the quality criterion and the feedback coefficients. In addition, as shown above, the method works in the presence of a small delay in the control loop.

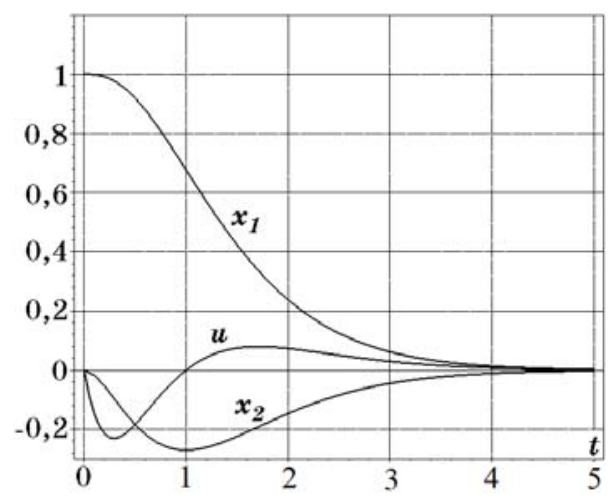

a

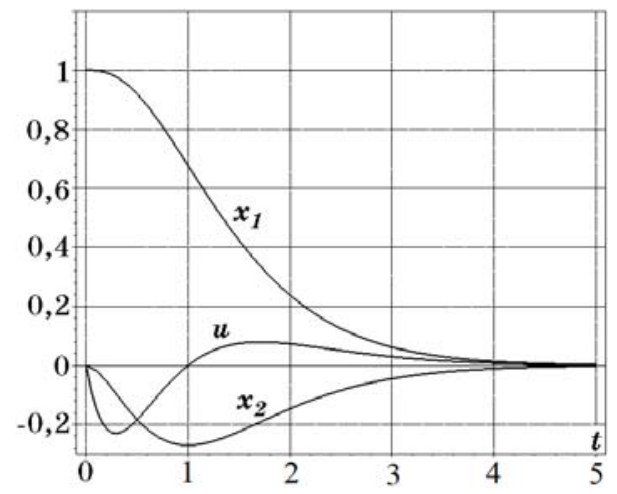

b

Figure 1 - Transient graphics obtained by ACOR (left) and modal synthesis (right) 

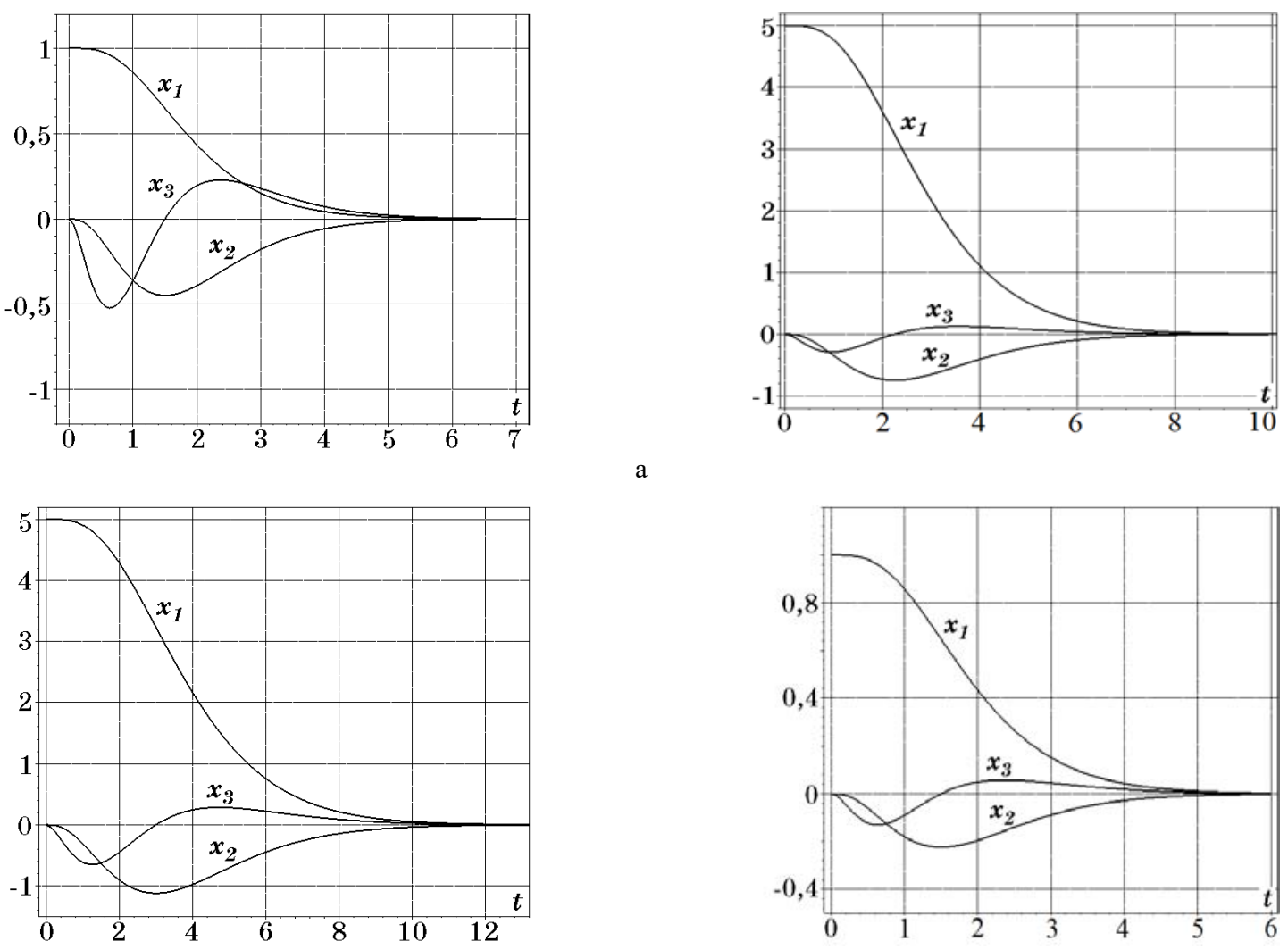

Figure 2 - Transient graphics obtained by ACOR (left) and modal synthesis (right)

\section{CONCLUSIONS}

The modal synthesis of linear closed stationary systems with the optimal control law (3) proposed in the article can provide the required dynamic properties in technological processes according to the given parameters. The procedure of modal synthesis of the optimal control law carries out on the method of uncertain coefficients proposed in the article. The difficulty of choosing the required eigenvalues overcomes the suggested procedure, construction and correction of the spectrum of roots of the closed-loop optimal control system of technological processes. Synthesis of closedloop optimal control systems is generalized to incompletely observed processes and processes with delay in the control loop. In addition, the proposed procedure of modal synthesis can be used for one class of non-stationary systems, for which the method of equivalent transformation proposed in [10] is valid. The simulation results confirm the correctness and effectiveness of the received results.

\section{REFERENCES}

1. Pupkov K. A., Egupov N. D. Methods of classical and modern theory of automatic control, Theory of optimization of automatic control systems. Moscow, The Bauman University Publishing House, 2004, Vol. 4, 744 p.

2. Malyshkin A. B. Problems and prospects of automation of technological processes at petrochemical enterprises
[Electronic resource]. Access mode: DOI: 10.18454/IRJ.2016.47.097.

3. Yanushevsky R. T. Management of objects with delay. Moscow, Nauka, 1978, 410 p.

4. Letov F. A. Analytical Design of Controllers/ Letov // Automation and telemechanics, 1960, No. 4, pp. 436-441. No. 5, pp. 561-568. No. 6, pp. 661-665. 1961, No. 4, pp. 425-435.

5. Kalman R. E. Contribution to the theory of optimal control, Bulletin of the society of Mechanics and Mathematicians, 1960, Vol. 12, No. 2, pp. 102-119.

6. Bystrov S. V., Grigoriev V. V., Pershin I. M. et al. The Synthesis of linear-quadratic control laws for continuoustime dynamic objects, International research journal of St. Petersburg State University, 2017, No. 2(56), pp. 97-100 DOI: https://doi.org/10.23670/IRJ.2017.56.052

7. Athans M., Falb P. L. Optimal Control: An Introduction to the Theory and Its Applications. North Chelmsford, Courier Corporation, 2013, $879 \mathrm{p}$.

8. Bass R. W. Improved on-off Missile Stabilization, Jet Propulsion, 1956, Vol.26, pp. 415-417.

9. Andreev Yu. N. Control of Finite-Dimensional Linear Objects. Moscow, Nauka, 1976, 424 p.

10. Melkumyan E. Yu., Soldatova M. A. Method of the equivalent conversion of one class of linear nonstationary systems, Adaptive Systems of Automatic Control InterBranch Scientific and technological Digest, 2015, Issue 1(26), pp. 102-105. https://doi.org/10.20535/15608956.26.2015.45515

Received 25.09.2019 Accepted 29.12.2019. 


\section{МЕТОД НЕВИЗНАЧЕНИХ КОЕФІЦІНТІВ У ЗАВДАННЯХ ОПТИМАЛЬНОЇ СТАБІЛІЗАЦІЇ ТЕХНОЛОГІЧНИХ ПРОЦЕСІВ}

Стенін О. А. - д-р техн. наук, професор кафедри технічної кібернетики, Київський політехнічний інститут ім. Ігоря Сікорського, Київ, Україна.

Дроздович І. Г. - канд. техн. наук, ст. науковий співробітник, Інститут телекомунікацій і глобального інформаційного простору НАН України, Київ, Україна.

Солдатова М. О. - ст. викладач кафедри автоматизованих систем обробки інформації та управління, Київський політехнічний інститут ім. Игоря Сикорского, Київ, Україна.

\section{АНОТАЦІ}

Актуальність В даній статті розглядається метод еквівалентного перетворення, зміст якого полягає в заміні деякого класу нестаціонарних систем стаціонарними, для яких методи оптимізації добре опрацьовані. Актуальність методу обумовлена тим, що у більшості методів оптимального управління, які розроблені для неперервних систем, задачі розглядаються у часовому просторі з використанням простору станів та теорії матриць. Відомо, що всі реальні об'єкти управління в той чи іншій мірі є нелінійними та нестаціонарними. Аналіз та синтез систем управління для таких об'єктів представляє собою складну математичну проблему, рішення якої до теперішнього часу отримано для деяких окремих випадків.

В результаті використання запропонованого методу, коли відома матриця змінних коефіцієнтів, задача оптимального управління нестаціонарною системою зводиться до рішення задачі оптимального управління еквівалентною стаціонарною системою, методи рішення якої достатньо відомі та добре опрацьовані.

Метод. Для досягнення поставленої мети запропоновано метод модального синтезу оптимальних законів стабілізації 3 використанням розробленого авторами методу невизначених коефіцієнтів

Результат. Розроблено алгоритм синтезу оптимального регулятора у випадках відсутності і наявності запізнювання в контурі управління. Запропонована методика вибору і корекції бажаного спектру коренів. Для усунення автоколивань при наявності запізнювання в контурі управління використовується метод Р. Бесса.

Висновок Запропоновано модальний синтез оптимальних законів стабілізації технологічних процесів на основі оригінального методу невизначених коефіцієнтів. Складність вибору шуканих власних значень долається запропонованою процедурою побудови і корекції спектру коренів в замкнутій системі оптимального управління. Для виключення виникнення стійких автоколивань (при наявності затримки) в процесі стабілізації поблизу заданої траєкторії пропонується використовувати метод Бесса. Результати моделювання підтверджують коректність і ефективність отриманих результатів.

КЛЮЧОВІ СЛОВА технологічний процес, лінійно-квадратична задача оптимізації, метод АКОР, модальний синтез, метод невизначених коефіцієнтів, вибір і корекція спектру коренів, метод Р. Бесса

\section{УДК 621.51}

\section{МЕТОД НЕОПРЕДЕЛЕННЫХ КОЭФФИЦИЕНТОВ В ЗАДАЧАХ ОПТИМАЛЬНОЙ СТАБИЛИЗАЦИИ} ТЕХНОЛОГИЧЕСКИХ ПРОЩЕССОВ

Стенин А. А. - д-р техн. наук, профессор кафедры технической кибернетики, Киевский политехнический институт им. Игоря Сикорского, Киев, Украина.

Дроздович И. Г. - канд. техн. наук, ст. научный сотрудник, Институт телекоммуникаций и глобального информационного пространства НАН Украины, Киев, Украина.

Солдатова М. А. - ст. преподаватель кафедры автоматизированных систем обработки информации и управления, Киевский политехнический институт им. Игоря Сикорского, Киев, Украина.

\section{АННОТАЦИЯ}

Актуальность. В данной статье рассматривается метод эквивалентного преобразования, смысл которого заключается в замене некоторого класса нестационарных систем стационарными, для которых методы оптимизации хорошо проработаны. Актуальность метода обусловлена тем, что в большинстве методов оптимального управления, разработанные для непрерывных систем, задачи рассматриваются во временном пространстве с использованием пространства состояний и теории матриц. Известно, что все реальные объекты управления в той или иной степени являются нелинейными и нестационарными. Анализ и синтез систем управления для таких объектов представляет собой сложную математическую проблему, решение которой до настоящего времени получено для некоторых частных случаев.

В результате использования предложенного метода, когда известна матрица переменных коэффициентов, задача оптимального управления нестационарной системой сводится к решению задачи оптимального управления эквивалентной стационарной системою, методы решения которой достаточно известные и хорошо проработанные.

Метод. Для достижения поставленной цели предложен метод модального синтеза оптимальных законов стабилизации с использованием разработанного авторами метода неопределенных коэффициентов.

Результаты. Разработан алгоритм синтеза оптимального регулятора в случаях отсутствия и наличия запаздывания в контуре управления. Предложена методика выбора и коррекции желаемого спектра корней. Для устранения автоколебаний при наличии запаздывания в контуре управления используется метод Р. Бэсса.

Выводы. Предложен модальный синтез оптимальных законов стабилизации технологических процессов на основе оригинального метода неопределенных коэффициентов. Сложность выбора искомых собственных значений преодолевается предложенной процедурой построения и коррекции спектра корней в замкнутой системе оптимального управления. Для 
исключения возникновения устойчивых автоколебаний (при наличии задержки) в процессе стабилизации вблизи заданной траектории предлагается использовать метод Бэсса. Результаты моделирования подтверждают корректность и эффективность полученных результатов.

КЛЮЧЕВЫЕ СЛОВА: технологический процесс, линейно-квадратичная задача оптимизации, метод АКОР, модальный синтез, метод неопределенных коэффициентов, выбор и коррекция спектра корней, метод Р. Бэсса.

\section{ЛІТЕРАТУРА / ЛИТЕРАТУРА}

1. Пупков К. А., Сгупов Н. Д. Методи класичної та сучасної теорії автоматичного управління / К. А. Пупков, Н. Д. Сгупов // Теорія оптимізації автоматичних систем управління. - М :: Видавництво університету Баумана, 2004. - Вип. 4 - 744 с.

2. Малишкін А. Б. Проблеми та перспективи автоматизації технологічних процесів на нафтохімічних підприємствах [Електронний ресурс] / Малишкін А. Б. Режим доступу: DOI: 10.18454 / IRJ.2016.47.097.

3. Янушевський Р. Т. Управління об'єктами із запізненням ( Р. Т. Янушевський. - М .: Наука, 1978. - 410 с.

4. Ф. Летов А. Аналітичне проектування контролерів / Летов // Автоматизація та телемеханіка. - 1960. - №4. C. 436-441, № 5. - C. 561-568, № 6. - C. 661-665, 1961. - № 4. - C. 425-435.

5. Kalman R. E. Contribution to the theory of optimal control / R. E. Kalman // Bulletin of the society of Mechanics and Mathematicians. - 1960. - Vol. 12, № 2. - P. 102-119.

6. Синтез законів лінійно-квадратичного управління для динамічних об'єктів безперервного часу
[C. В. Бистрова, В. В. Григор'єва, І. М. Першина та ін.] // Міжнародний науковий журнал Петербурзького державного університету. - 2017.- № 2 (56). - С. 97-100. DOI: https://doi.org/10.23670/IRJ.2017.56.052

7. AthansOptimal Control: An Introduction to the Theory and Its Applications / M. Athans, P. L. Falb. - North Chelmsford : Courier Corporation, $2013-879$ p.

8. Bass R. W. Improved on-off Missile Stabilization / R. W. Bass // Jet Propulsion. - 1956. - Vol. 26. - P. 415417.

9. Андрєєв Ю. Н. Контроль кінцевомірних лінійних об'єктів / Ю. Н. Андрєєва. - М. : Наука, 1976. - 424 с.

10. Мелкумян Е. Ю. Метод еквівалентного перетворення одного класу лінійних нестаціонарних систем / Є. Ю. Мелкумян, М. А. Солдатова // Адаптивні системи автоматичного управління міжгалузевим науковотехнічним дайджестом. - 2015. - Випуск 1 (26). C. $102-105$.

https://doi.org/10.20535/15608956.26.2015.45515 